\title{
Use of Waste Glass Powder As A Partial Replacement of Cement In Fibre Reinforced Concrete
}

\author{
Mohammad Shoeb Sayeeduddin ${ }^{1}$, Mr. F.I. Chavan ${ }^{2}$ \\ ${ }^{I}$ (PG Student, Department of Civil Engineering, SSBTCET, NMU, Jalgaon, India) \\ ${ }^{2}$ (Assistant. Professor, Department of Civil Engineering, SSBTCET, NMU, Jalgaon, India)
}

\begin{abstract}
Concrete industry is one of the largest consumers of natural resources due to which sustainability of concrete industry is under threat. The environmental and economic concern is the biggest challenge concrete industry is facing. In this paper, the issues of environmental and economic concern are addressed by the use of waste glass powder as partial replacement of cement in concrete. Cement was replaced by waste glass powder as $0 \%$ to $40 \%$ in increment of 5\% in M20. The concrete specimens were tested for compressive strength, splitting tensile strength, flexural strength and workability at 7 days, 28 days, 60days, 90days and 180days of age and the results obtained were compared with those of normal concrete. The results concluded the permissibility of using waste glass powder as partial replacement of cement at $20 \%$ by weight.
\end{abstract}

Keywords: Fibre reinforced concrete, waste glass powder, strength, sustainable concrete.

\section{Introduction}

The environmental impact of concrete, its manufacture and applications, is critical. Some effects are harmful; others good. Rest all depend on use circumstances of concrete. A main ingredient of concrete is cement, which has its own environmental impacts and contributes largely to those of concrete. The cement industry is one of the primary industrial producers of carbon dioxide $\left(\mathrm{CO}_{2}\right)$, creating up to $6 \%$ of worldwide man-made emissions of this gas, of which 50\% is from the chemical process and $40 \%$ from burning fuel. Glass is an amorphous solid that has been found in various forms for thousands of years and has been manufactured for human use since 12,000 BC. Glass is one the most versatile substances, used in many applications and in a wide variety of forms. The interest of the construction community in using waste or recycled materials in concrete is increasing because of the emphasis placed on sustainable construction. Glass is an inert material which could be recycled and used many times without changing its chemical property (Aimin Xu and Ahmad shayam, 2004). Efforts have been made in the concrete industry to use waste glass powder as partial replacement of cement. Waste glass when ground to a very fine powder shows pozzolanicproperties as it contains $\mathrm{SiO}_{2}$ and therefore to some extent can replace cement in concrete and contribute in strength development. Glass is amorphous material with high silica content, thus making it potentially pozzolanic when particle size is less than 75 micron. This paper reports the results of an experimental investigation on the use of glass powder in partially replacement cement in fibre reinforced concrete and summarized the behavior of concrete involving partial replacement of cement by waste glass powder $0 \%$ to $40 \%$ at interval of $5 \%$ each.

Table No. 1: Chemical composition of cement and glass

\begin{tabular}{|l|l|l|l|}
\hline Sr. No. & Composition $(\%$ by mass $)$ / Property & Cement & Waste glass powder \\
\hline 1. & Silica $\left(\mathrm{SiO}_{2}\right)$ & 20.2 & 72.5 \\
\hline 2. & Alumina $\left(\mathrm{Al}_{2} \mathrm{O}_{3}\right)$ & 4.7 & 0.4 \\
\hline 3. & Iron Oxide $\left(\mathrm{Fe}_{2} \mathrm{O} 3\right)$ & 3.0 & 0.2 \\
\hline 4. & Lime $(\mathrm{CaO})$ & 61.9 & 9.7 \\
\hline 5. & Magnesia $(\mathrm{MgO})$ & 2.6 & 3.3 \\
\hline 6. & Sodium oxide $\left(\mathrm{Na}_{2} \mathrm{O}\right)$ & 0.19 & 13.7 \\
\hline 7. & Potassium oxide $\left(\mathrm{K}_{2} \mathrm{O}\right)$ & 0.82 & 0.1 \\
\hline 8. & Sulphur trioxide $\left(\mathrm{SO}_{3}\right)$ & 3.9 & - \\
\hline 9. & Loss of ignition & 1.9 & 0.36 \\
\hline 10. & Fineness \% passing by sieve & 97.4 & 80 \\
\hline 11. & Unit Weight kg/m & 3150 & 2579 \\
\hline 12. & Specific Gravity & 3.15 & 2.58 \\
\hline
\end{tabular}

II. Materials Used For Mix

For preparation of mix of grade M20, materials used and their specification details are given below:

1. Cement: The cement used in this study was 43 grade ordinary Portland cement (OPC) confirming to IS: 8112-1989.

2. Fine aggregate: Locally available sand confirming to zone II with specific gravity 2.62 was used. The testing of sand was done as per Indian specification IS: 2386 (Part III)-1963. 
3. Coarse aggregate: Coarse aggregate used was $20 \mathrm{~mm}$ and down size and specific gravity 2.76 . Testing was done as per Indian standard specification IS: 2386 (Part III)-1963.

4. Glass powder: Waste glass available locally was collected and made into glass powder. Glass waste is very hard material. Before adding glass powder in the concrete it has to be powdered to desired size. In this experiment glass powder having partials size less than 90 micron was used.

5. Water: the water used was portable, fresh, colorless, odourless, and tasteless water that is free from organic matter of any type.

6. Polypropylene fibers: polypropylene fibers are specially engineered for use in concrete and mortar as a micro reinforcement system. They possess very high tensile strength, but their low modulus of elasticity and higher elongation do not contribute to the flexural strength. Polypropylene (PP) is a versatile thermoplastic material, which is produced by polymerizing monomer units of polypropylene molecules into very long polymer molecules or chains in the presence of a catalyst under carefully, controlled heat and pressure. Propylene is an unsaturated hydrocarbon, containing only carbon and hydrogen atoms:

\section{$\mathrm{CH} 2=\mathrm{CH}$ \\ $\mathrm{CH} 3$}

(Propylene)

\section{Test Conducted}

Experimentation was done on prepared mix of grade M20 with w/c ratio 0.45 .3 sets of mix were prepared for testing, normal mix, mix inn which cement is replaced with glass powder and mix in which glass powder and $0.03 \%$ of glass fibres were used. For investigation of results following tests were conducted:

- Compression Test

- Flexural Test

- $\quad$ Split tensile Test

- Workability(Slump Cone Test)

\section{Results}

The tests were conducted on 7dyas, 28days, 60days, 90days and 180days. Results were analyzed graphically and are listed below:

- Compression Test:

Mix M20 (1:1.34:3.2)w/c:0.45 replace by glass powder

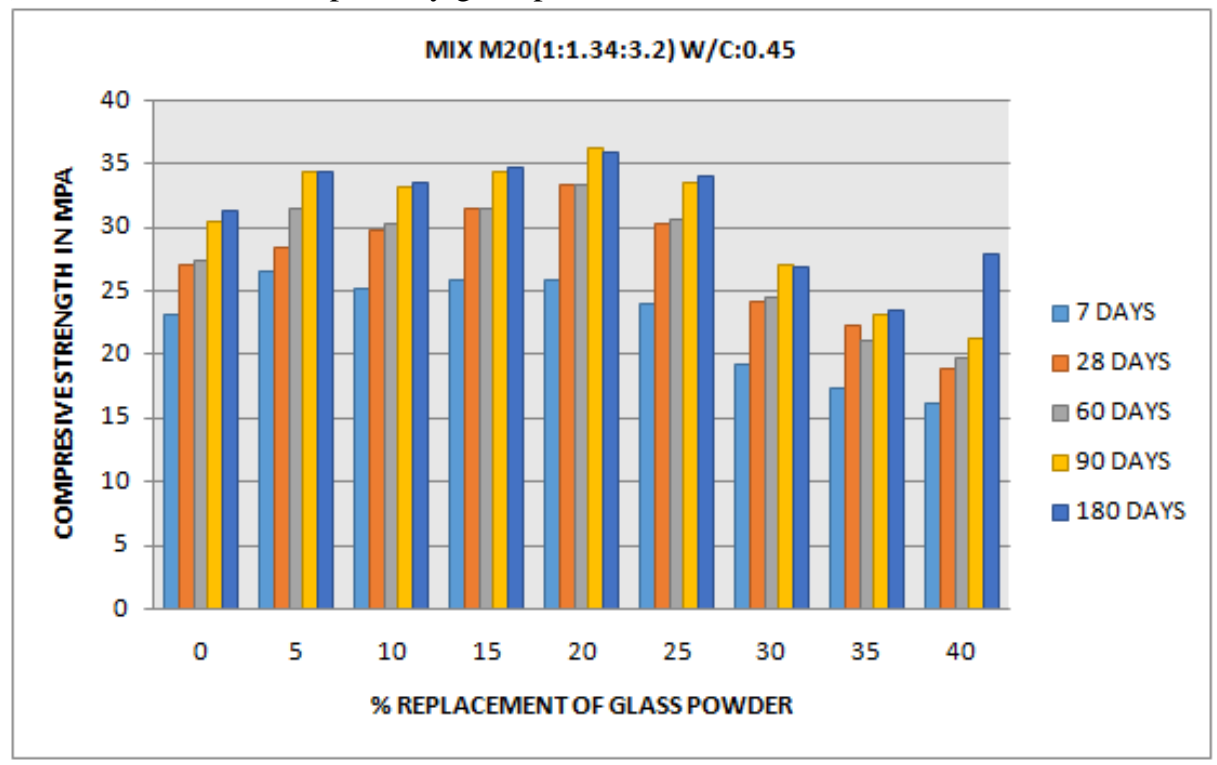


Mix M20(1:1.34:3.2) w/c:0.45 replace by glass powder $+0.03 \%$ glass fibre

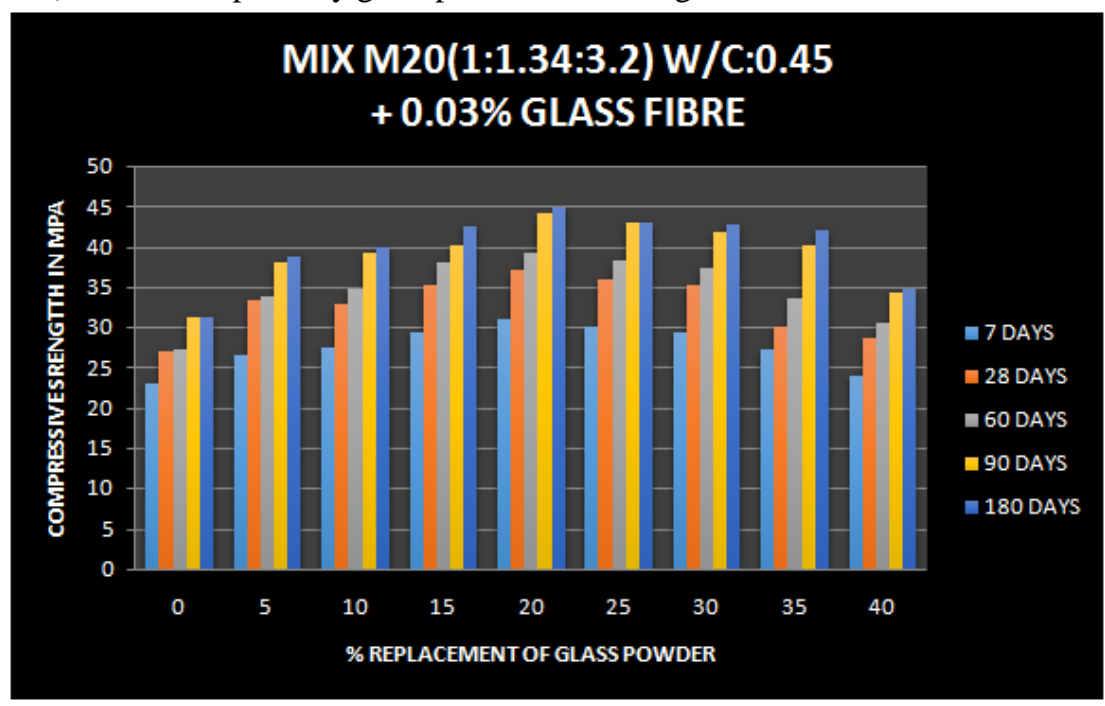

- Flexure test:

Mix M20(1:1.34:3.2) w/c:0.45 replace by glass powder

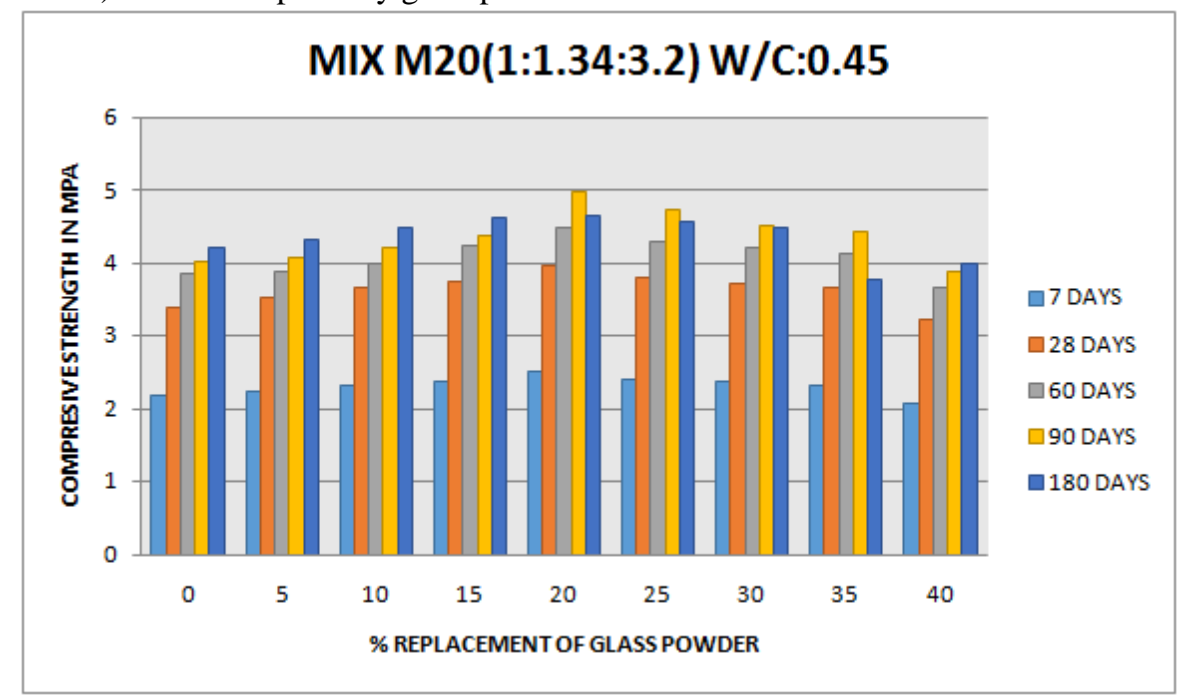

Mix M20(1:1.34:3.2) w/c:0.45 replace by glass powder $+0.03 \%$ glass fibre

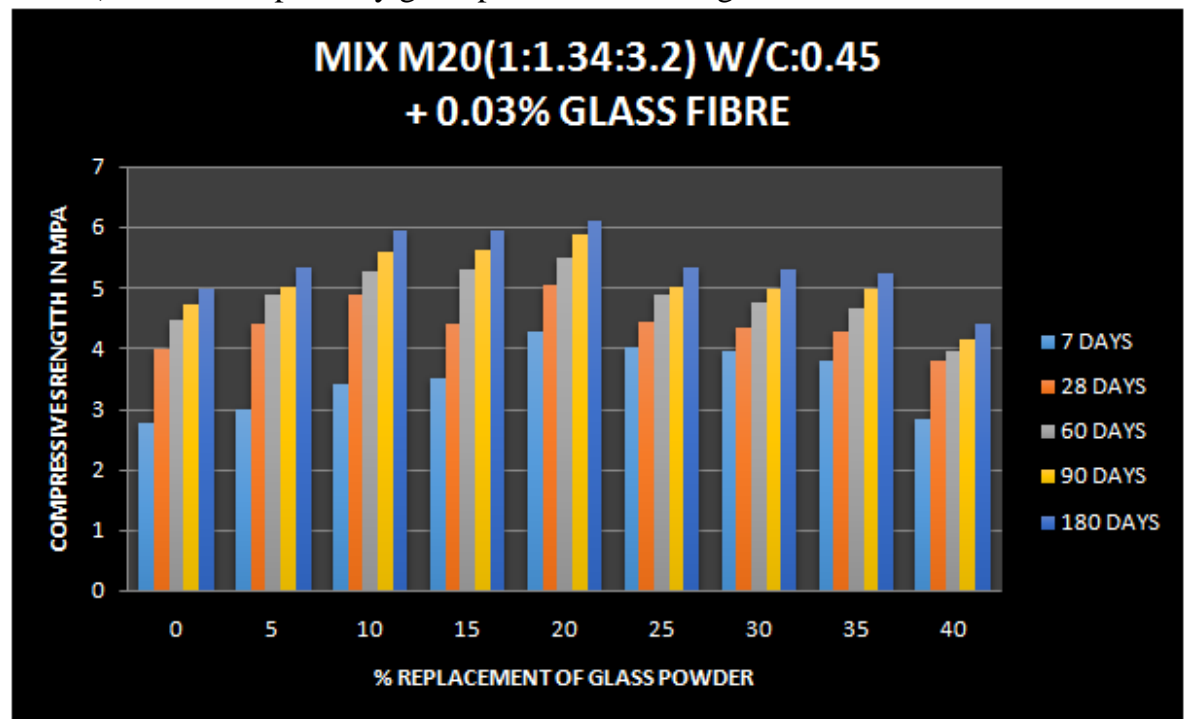


- $\quad$ Split End Tensile test:

Mix M20(1:1.34:3.2)w/c:0.45 replace by glass powder

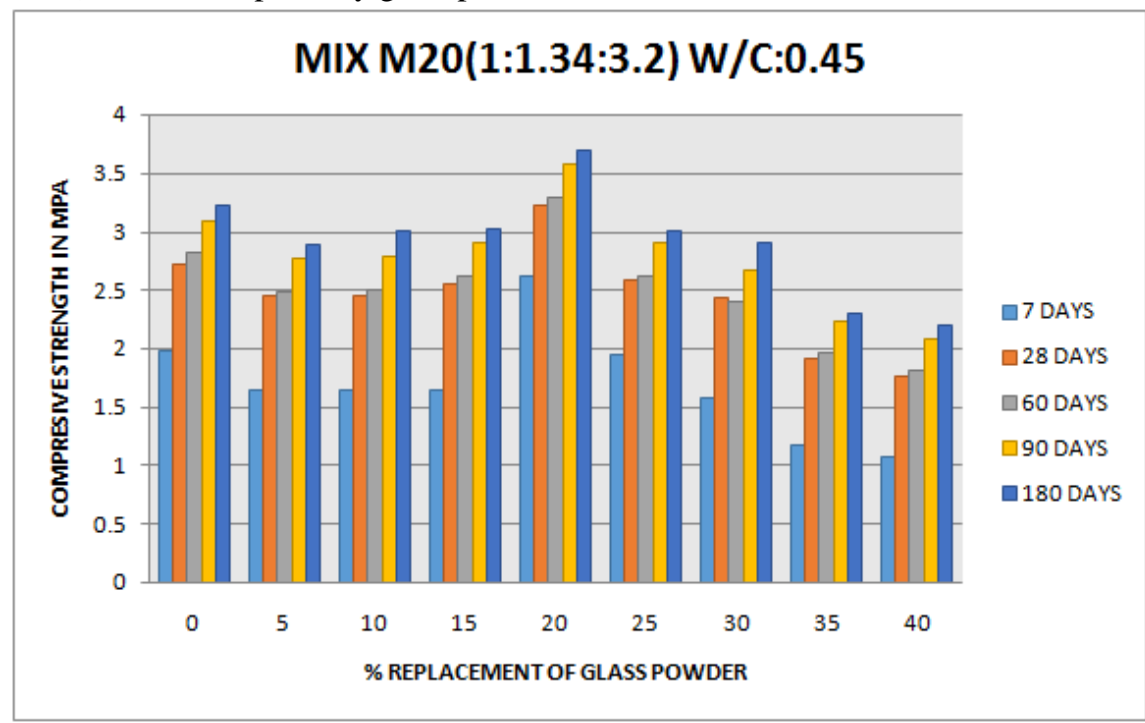

Mix M20(1:1.34:3.2) w/c:0.45replace by glass powder $+0.03 \%$ glass fibre

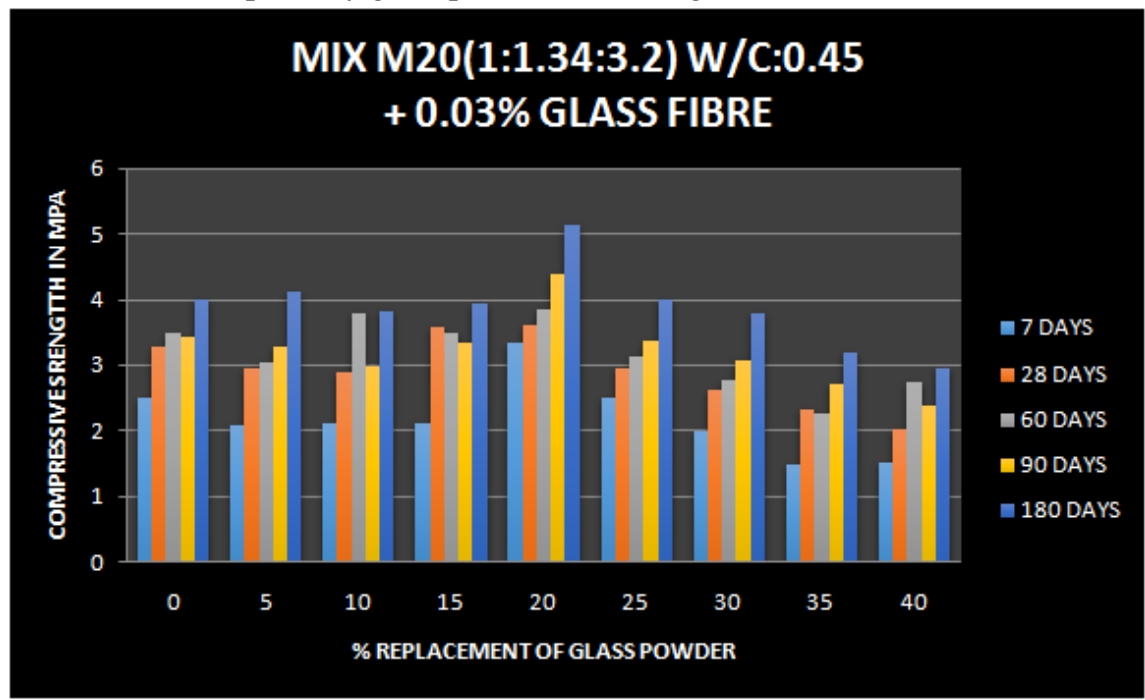

- Workability Test:

Slump Height $(\mathrm{mm})$

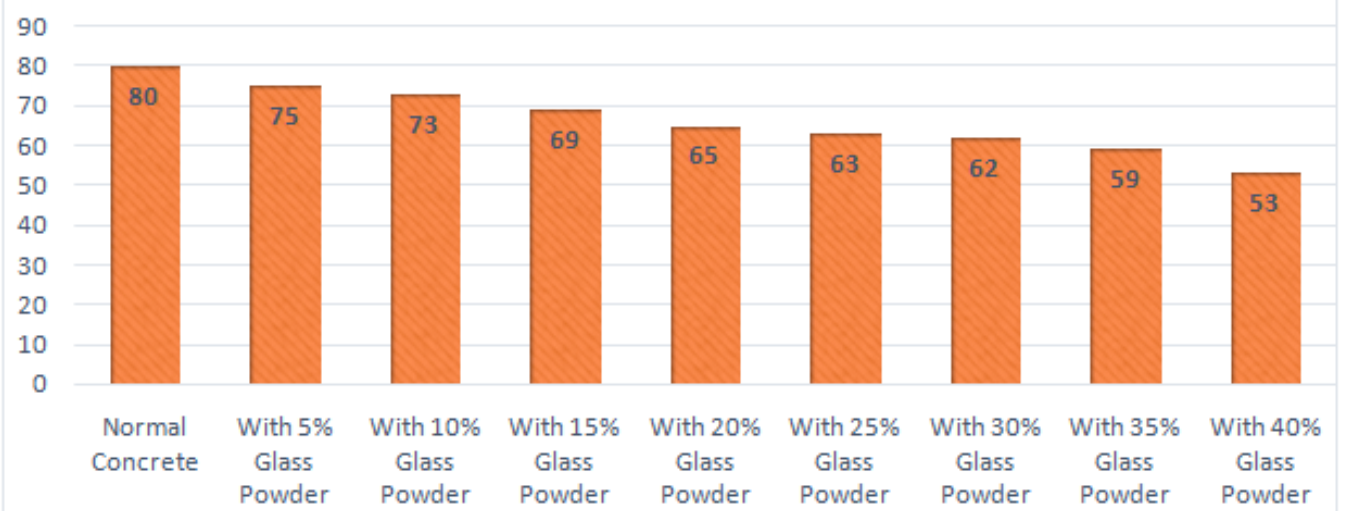




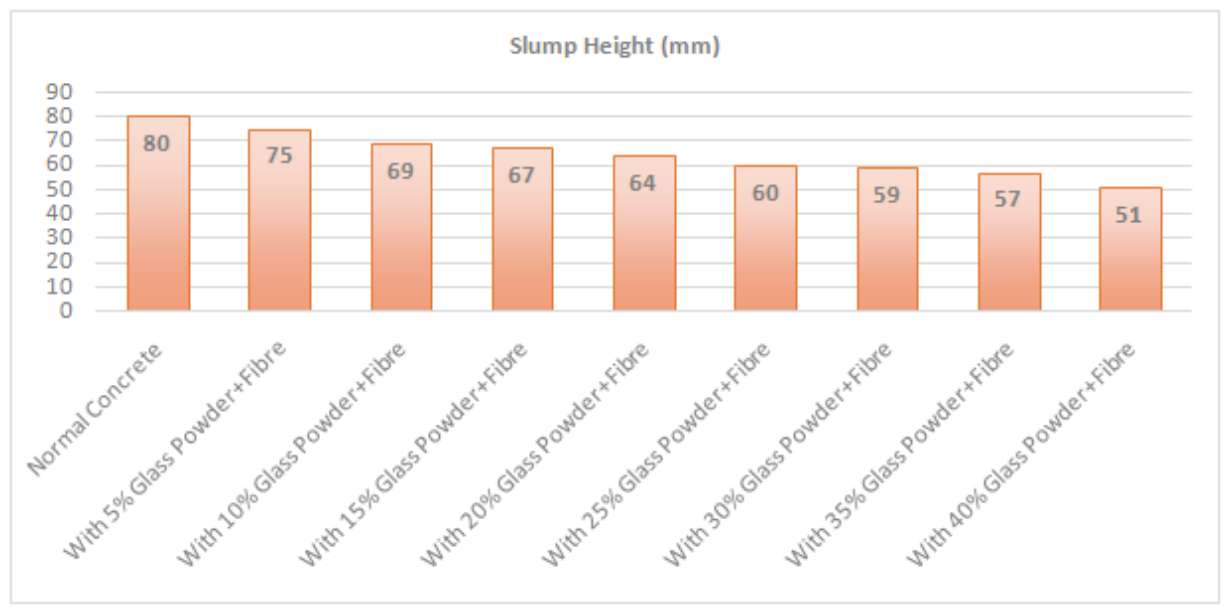

\section{Conclusions}

As the percentage of replacement of cement with glass powder increases strength increases up to $20 \%$ and beyond that it decreases. The highest percentage increases in the compressive strength was about $23 \%$ and flexural strength was about $17 \%$ and split tensile strength was about $18 \%$ at $20 \%$ replacement level. The increases in strength up to $20 \%$ replacement of cement by glass powder may be due to the pozzolonic reaction of glass powder due to high silica content. Also it effectively fills the voids and gives a dense concrete microstructure. However, beyond $20 \%$ the dilution effect takes over and the strength starts to drop. Thus it can be concluded that $20 \%$ was the optimum level for replacement of cement with glass powder. As the glass content increases workability decreases. As there is a reduction in fineness modulus of cementations material, quantity of cement paste available is less for providing lubricating effect per unit surface area of aggregate. Therefore, there is restrain on the mobility.

\section{References}

[1]. Khatib J.M., Sohl H.S., H.S. Sohl and Chileshe N. (2012) "Glass Powder Utilisation in Concrete Production" European Journal of Applied Sciences 4 (4): 173-176, 2012 ISSN 2079-2077 @ IDOSI Publications,

[2]. Patel Dhirendra, Yadav R.K. and Chandak R (2012) "Strength Characteristics of Pre Cast Concrete Blocks Incorporating Waste Glass Powder" ISCA Journal of Engineering Sciences Vol. 1(1)July, [International Science Congress Association]

[3]. JangidJitendra B. and Saoji A.C. (2014) "Experimental investigation of waste glass powder as the partial replacement of cement in concrete production" IOSR Journal of Mechanical and Civil Engineering (IOSR-JMCE) e-ISSN: 2278-1684, p-ISSN: 2320-334X [International Conference on Advances in Engineering and Technology -(ICAET-2014)]

[4]. Idir R., Cyr M., and Tagnit-Hamou A. (2009) "Use of Waste Glass as Powder and Aggregate in Cement-Based Materials" SBEIDCO $-1^{\text {st }}$ International Conference on Sustainable Built Environement Infrastructures in Developing Countries ENSET Oran (Algeria) -

[5]. Chikhalikar S.M. and Tande S.N. (2012) "An Experimental Investigation On Characteristics Properties of Fibre Reinforced Concrete Containing Waste Glass Powder as Pozzolona" 37th Conference on Our World in Concrete and Structures, Singapore, August.

[6]. Dali J.S. and Tande S.N. (2012) "Performance of Concrete Containing Mineral Admixtures Subjected to High Temperature" 37th Conference on Our World in Concrete and Structures, Singapore, August.

[7]. Shayan Ahmad (2002) "Value-added Utilisation of Waste Glass in Concrete" IABSE Symposium Melbourne.

[8]. Bajad M.N. ,ModheraC.D.and Desai A.k.(2011) "Effect of Glass on Strength of Concrete Subjected to Sulphate Attack" International Journal of Civil Engineering Research and Development (IJCERD), ISSN 2228-9428(Print) ISSN 2248 9436(Online), Volume 1, Number 2.

[9]. Malik M. Iqbal, Bashir Muzafar, Ahmad Sajad, Tariq Tabish, and Chowdhary Umar (2013) "Study of Concrete Involving Use of Waste Glass as Partial Replacement of Fine Aggregates" IOSR Journal of Engineering (IOSRJEN) e-ISSN: 2250-3021, p-ISSN: 2278-8719 Vol. 3, Issue 7(July).

[10]. Nwaubani Sunny O. and Poutos Konstantinos I.(2013) "The Influence of Waste Glass Powder Fineness on the Properties of Cement Mortars" International Journal of Application or Innovation in Engineering and Management (IJAIEM) Volume 2, Issue 2, ISSN $2319-4847$.

[11]. Osmani M. and Pappu A. (2012) "Utilisation of Glass Reinforced Plastic Waste in Concrete and Cement Composites" Proceedings of Second International Conference on Sustainable Construction Materials and Technologies, Ancona Italy

[12]. T.R. Naik and G. Moriconi (2005) "Environmental-friendly durable concrete made with recycled materials for sustainable concrete construction" CANMET/ACI International Symposium on Sustainable Development of Cement and Concrete, Toronto, Canada, October.

[13]. GopalakrishnanRamasamy and GovindarajanDharshnamoorthy (2011) "Compressive Strength and Electron Paramagnetic Resonance Studies on Waste Glass Admixtured Cement" New Journal of Glass and Ceramics, 2011, Published Online October

[14]. PatilDhanraj Mohan and Dr.SangleKeshav K (2013) "Experimental Investigation of Waste Glass Powder as Partial Replacement of Cement in Concrete". International Journal of Advanced Technology in Civil Engineering, ISSN: 2231 -5721, Volume-2, Issue-1, 2013.

[15]. VasudevanGunalaan and Pillay Seri GanisKanapathy "Performance of Using Waste Glass Powder In Concrete As Replacement Of Cement" American Journal of Engineering Research (AJER) e-ISSN : 2320-0847 p-ISSN : 2320-0936 Volume-02, Issue-12 
[16]. Roz-Ud-Din and Nassar, ParvizSoroushian (2012) "Strength and durability of recycled aggregate concrete containing milled glass as partial replacement for cement" Construction and Building Materials 29.

[17]. Oliveira L.A Pereira de, Gomes J.P. and Castro Santos P. (2008) "Mechanical and Durability Properties of Concrete with Ground Waste Glass Sand" DBMC International Conference on Durability of Building Materials and Components ISTANBUL, Turkey 11 14 May.

[18]. Oliveira L.A Pereira de, Gomes J.P. and Castro Santos P. (2010) "Optimization of pozzolanic reaction of ground waste glass incorporated in cement mortars" "Fundação para Ciência e Tecnologia" POCI/ECM/55588/2004.

[19]. Wang Her-Yung and HouTsung-Chin Hou (2011) "A Study of Elevated Temperatures on the Strength Properties of LCD Glass Powder Cement Mortars” Integrated Waste Management - Volume IISBN:978-953-307-469 